\title{
Cultured Ecosystems
}

Not too long ago I watched a television program about the cultured pearl industry, and I was struck by the similarities between that endeavor and our efforts to restore ecosystems. I am going to describe those similarities here and explain why I think the lessons of the cultured pearl industry may hold some value for the restorationist.

First, a brief primer about pearls. Pearls can be obtained from both seawater and freshwater mollusks. Natural pearls are crystalline concretions of nacre-a substance that a mollusk will secrete around any "irritant" that becomes lodged inside its shell. This type of pearl has been used by humans in many parts of the world, including the Americas, for more than 6,000 years. Overharvesting of natural pearls - first in the Old World and more recently in the New World-led to a dramatic decline in natural pearls by the mid-1800s.

At the end of the 19th century, three Japanese men-Tokichi Nishikawa, Tatsuhe Mise, and Kokichi Mikimoto-each began experimenting with ways to produce round, artificial pearls. The Mise-Nishikawa method for culturing whole pearls, which was patented in 1908, serves as the basis for pearl culturing. This method, which was later improved and patented by Mikimoto in 1916, involves surgically implanting a graft of living mantle from a donor oyster into an oyster from a isolated strain that is known for producing pearls. Technicians then carefully place a tiny sphere of Mississippi River mussel shell onto the newly implanted mantle. The implanted oyster and its compatriots are then placed into 7 to 10 feet of water, typically in cages that are suspended from rafts. They are cared for and monitored until harvest, which is about two years after the implant. The pearl-growers open each oyster to see if it has successfully secreted its nacre around the implanted sphere, and then they sort the pearls by size and color. According to Mikimoto, Inc., one of the world's largest cultured saltwater pearl producers, only 5 percent of their oysters produce high-quality pearls, 28 percent produce marketable pearls, and the remainder either produce unmarketable pearls or die. Despite these seemingly unfavorable odds, Mikimoto, Inc. and other pearl producers stay in business and cultured pearls, which represent 90 percent of all the pearls sold, remain in high demand.

I know that good analogies are difficult to make and often fraught with unsubstantiated generalities, but I think there are several similarities between the cultured pearl industry and the practice and business of ecological restoration. First, both enter- prises provide, or attempt to provide, a replacement for a depleted population of a natural entity. Second, they are honest efforts that produce results that are not fakes or imitations, but are not entirely natural, either. Third, both require human intervention, research, and innovation. Fourth, both activities are acts of cultivation that require working with the vagaries of natural processes to achieve a desired outcome. Finally, while both practices have their failures, when they are successful they produce something of lasting value.

While I suspect that some might argue with me about any and all of these similarities, it is the notion that both cultured pearl production and ecological restoration produce something of lasting value that I would like to explore more closely. I want to take a closer look because while I think both processes are similar in this respect, I also sense a significant dissimilarity in the acknowledgment of their perceived economic value. I wonder, for example, what would happen if I offered average citizens the choice between a $\$ 20,000$ string of Mikimoto pearls and a similarly priced, high-quality restored prairie, woodland, or wetland. Which would they choose and how would they decide?

Let's say that I gave the citizens a month to seek the advice of some appraisers. What would they learn? First, they would probably find out that the pearls are valued at $\$ 20,000$ because, even though it is a somewhat subjective field, there are standards for rating an individual pearl as well as a string of pearls. These standards include luster, size, color, origin, rarity, shape, arrangement, and consistency of size and color within a string. In other words, jewelry appraisers everywhere have a set of values upon which to make their appraisal. Land appraisals, on the other hand, are typically appraisals of potential value-number of lots per acre, distance to transportation corridors and other utilitiesrather than judgments of value for existing uses. Moreover, and with the possible exception of some purchases by land trusts or The Nature Conservancy, land is rarely considered solely on the basis of its ecological quality or the number and type of its ecological inhabitants. So, would the practical citizen decide then on the sure thing-the string of pearls-or would they take the chance or feel some sort of environmental responsibility and accept the restored land? I'm afraid that pearls would be chosen more often than the restored land.

Most economists will tell you that creating value in something depends on convincing consumers that the item has some 
acceptable combination of prestige, quality, proper price, service, relevance to their life, and fun. What does the cultured pearl industry example show us in this context? I see a number of things that we might do to help establish the economic value of a restoration project. First, we have to educate the consumers of land that restored properties carry a certain amount of "green" prestige; that being the owner of a restored property has meaning in their life and the life of their community. Second, we need to emphasize the physical beauty as well as the biological diversity of restored landscapes. Third, restorationists must make clear to landowners that restorations may be expensive because our efforts require hard, often experimental, work that is always subject to the vagaries of weather and other uncertainties.

Finally, the cultured pearl industry has another message, namely, that we need to be realistic and accept our role as builders of cultured ecosystems-no matter whether our work involves restoring ecological and social processes in a contemporary landscape, like the farmlands Laura Jackson describes in this issue, or restoring a combination of historic communities and their ecological and social processes as is commonly done now in natural areas, parks, and other "wild" areas.

Dave Egan

Once in a while a curious weed unknown to me,

Needing a name from my books;

Once in a while a letter from Yeomans.

Out of the musselshells gathered along the shore

Sometimes a pearl with a glint like meadow rue:

Then betimes a letter from Tyndall in England, Stamped with the stamp of Spoon River.

I, lover of Nature, beloved for my love of her,

Held such converse afar with the great

Who knew her better than I.

Oh, there is neither lesser nor greater,

Save as we make her greater and win

from her keener delight.

With shells from the river cover me, cover me.

I lived in wonder, worshipping earth and heaven.

I have passed on the march eternal of endless life.

Edgar Lee Masters

Spoon River Anthology (1915) 